\title{
SOSIALISASI SISTEM ADMINISTRASI PERPAJAKAN DALAM MENINGKATKAN KEPATUHAN PENGUSAHA KENA PAJAK (PKP) DI WILAYAH TULUNGAGUNG
}

\section{OLEH :}

SINDY

GRESI AGNE FEBYYASARI
(Sindyea09@gmail.com)

(gresiagne03@gmail.com)

\section{PRODI MANAJEMEN \\ UNIVERSITAS TULUNGAGUNG}

\begin{abstract}
Abstrak
Penelitian ini bertujuan untuk Mengetahui mekanisme pajak dan waktu membayar pajak bagi pengusaha serta mengetahui pendapat pengusaha untuk kebijakan perpajakan yang ada di Tulungagung. Selain itu, penelitian ini juga bertujuan untuk mengetahui pengaruh soialisasi perpajakan terhadap kepatuhan perpajakan secara langsung.

Metode analisis yang digunakan adalah metode kualitatif, penelitian ini yaitu mengunakan analisis deskriptif dengan menggambarkan kenyataan atau keadaankeadaan atas suatu objek dalam bentuk uraian kalimat berdasarkan keterangan dari pihak-pihak yang berhubungan langsung dengan penelitian ini.

Hasil penelitian ini membuktikan bahwa sosialisasi perpajakan memiliki pengaruh terhadap pengetahuan perpajakan dan kepatuhan perpajakan. BAPENDA bekerja sama dengan Pemerintah desa telah melakukan upaya sosialisasi perpajakan di balai desa. Selain itu mereka juga bekerja sama dengan beberapa pihak untuk dapat melakukan sosialisasi baik melalui media elektronik maupun media cetak.

Kata Kunci: Sosialisasi Perpajakan, Sitem Adminitrasi Perpajakan, Kepatuhan Perpajakan.
\end{abstract}




\section{PENDAHULUAN}

Pajak sebagai sumber penerimaan Negara digunakan untuk mebiayai pengeluaran rutin dan juga membiayai pembangunan. ${ }^{1}$ Oleh karena itu upaya untuk meningkatkan penerimaan dari sektor pajak sangatlah penting, karena dana yang dihimpun dari rakyat atau dari pemerintah.Untuk itu Pemerintah melauli Direktorat Jendral Pajak berupaya untuk senantiasa meningkatkan penerimaan Negara dari sektor Pajak. Bergbagai upaya dilakukan oleh Direktorat Jendral Pajak salah satunya melalui Reformasi di bidang administrasi perpajakan yang lebih modern dengan memanfaatkan teknologi Informasi, yang tujuan dari Reformasi ini yaitu untuk meningkatkan kepercayaan wajib Pajak terhadap administrasi perpajakan, dan meningkatkan produktivitas aparat perpajakan atau fiskus.

Dalam menghimpun penerimaan dari sektor pajak, yang pertama harus dilakukan oleh pemerintah dalam hal ini Direktorat Jendral Pajak adalah dengan meningkatkan kepercayaan wajib pajak mengenai administrasi pajak yang kemudian akan menimbulkan kepatuhan sukarela dari wajib pajak sehingga penerimaan Negara pun akan meningkat. Keberhasilan penerimaan pajak, perlu di ingatkan beberapa sasaran administrasi perpajakan, (1) meningkatkan kepatuhan para pembayar pajak, dan (2) melaksanakan ketentuan perpajakan secara seragam untuk mendapatkan penerimaan maksimal dengan biaya yang optimal. Pengukuran efektifitas administrasi perpajakan yang lebih akurat adalah dengan mengukur berapa besarnya jurang kepatuhan (tax gap), yaitu selisih antara penerimaan yang sesungguhnya dengan pajak potensial dengan tingkat kepatuhan dari masing-masing sektor perpajakan (Mardiasmo, 2011:294).

Kepatuhan wajib pajak (tax compliance) dapat diidentifikasi dari kepatuhan wajib pajak dalam mendaftarkan diri, kepatuhan untuk menyetorkan kembali surat pemberitahuan (SPT), kepatuhan dalam penghitungan dan pembayaran pajak. terhutang, dan kepatuhan dalam pembayaran tunggakan. Isu

\footnotetext{
${ }^{1}$ Firdaus Aprian Zuhdi, Topowijono, and Devi Farah Azizah, 'PENGARUH PENERAPAN E-SPT DAN PENGETAHUAN PERPAJAKAN TERHADAP KEPATUHAN WAJIB PAJAK (Studi Pada Pengusaha Kena Pajak Yang Terdaftar Di KPP Pratama Singosari)', 7.1 (2015), 1-7.
} 
kepatuhan menjadi penting karena ketidakpatuhan secara bersamaan akan menimbulkan upaya menghindarkan Pajak, seperti tax evasion dan tax avoidance, yang mengakibatkan berkurangnya penyetoran dana pajak ke kas Negara.

Tuntutan akan peningkatan penerimaan, peningkatan kesadaran dan kepatuhan wajib pajak serta perbaikan-perbaikan dan perubahan mendasar dalam segala aspek perpajakan menjadi alasan dilakukannya reformasi perpajakan. Reformasi perpajakan tersebut dapat berupa penyempurnaan terhadap kebijakan perpajakan dan sistem administrasi perpajakan sehingga bisa meningkatkan kepatuhan wajib pajak dalam mematuhi kewajiban perpajakannya, meningkatkan tanggung jawab aparatur pemerintah agar tidak melakukan kecurangan dan melayani masyarakat dengan sebaik-baiknya dan dapat meningkatkan potensi penerimaan pajak yang tersedia dapat dipungut secara optimal. Kalau ditinjau dari konsep produktivitas penerimaan pajak, jika organisasi ingin meningkatkan penerimaan pajaknya, maka organisasi harus respon terhadap perubahan yang terjadi. $^{2}$

Pajak adalah kontribusi wajib kepada negara yang terutang oleh orang pribadi atau badan yang bersifat memaksa berdasarkan Undang-Undang, dengan tidak mendapatkan imbalan secara langsung dan digunakan untuk keperluan negara bagi sebesar-besarnya kemakmuran rakyat. Pembayaran pajak merupakan perwujudan dari kewajiban kenegaraan dan peran serta Wajib Pajak untuk secara langsung dan bersama-sama melaksanakan kewajiban perpajakan untuk pembiayaan negara dan pembangunan nasional. Sesuai falsafah undang-undang perpajakan, membayar pajak bukan hanya merupakan kewajiban, tetapi merupakan hak dari setiap warga Negara untuk ikut berpartisipasi dalam bentuk peran serta terhadap pembiayaan negara dan pembangunan nasional.

Wajib Pajak yaitu pemegang atau pemilik usaha memiliki kewajiban membayar pajakjuga mempunyai hak sesuai dengan ketentuan peraturan perundang-undangan perpajakan. Seperti salah satu haknya adalah orang yang menjalankan sebuah bisnis seperti aktivitas jual-beli, termasuk produksi barang

\footnotetext{
${ }^{2}$ Mufti Rahmatika, 'ANALISIS FAKTOR-FAKTOR YANG BERPENGARUH TERHADAP KESADARAN KEWAJIBAN PERPAJAKAN PADA SEKTOR USAHA KECIL DAN MENENGAH (UKM) Diajukan', 2010.
} 
dan lain sebagainya. Yang mana, tujuan pengusaha yaitu memperoleh keuntungan dari aktivitas usaha jual-beli dan menanggung risiko bisnis yang dijalankan seperti gagal produksi, penurunan penjualan, hingga terparah mengalami gulung tikar.

Apabila diperhatikan dengan lebih seksama, selama ini perekonomian dalam negeri secara umum masih buruk, tetapi harus kita akui bahwa beberapa sektor usaha (terutama sektor swasta), masih menunjukan kinerja yang cukup bagus. Usaha yang bisa dikatakan bertahan hidup dalam segala situasi dan kondisi tersebut kebanyakan adalah Usaha Mikro Kecil dan Menengah. Banyaknya usahausaha tersebut, baik yang berskala kecil maupun menengah dengan sungguhsungguh merupakan sumber pajak yang dapat dipergunakan untuk menambah pendapatan Negara. Salah satu faktor yang mendasari Negara berkembang memandang pentingnya keberadaan Usaha Mikro Rendahnya tingkat kepatuhan Wajib Pajak untuk memenuhi kewajiban perpajakannya masih rendah apabila dibandingkan dengan tingkat pertumbuhan usaha.

Tingkat kepatuhan Wajib Pajak yang rendah juga salah satu pemacu pemerintah daerah melakukan pertimbangan yang matang dalam menentukan kebijakan fiskal yang diharapkan akan meningkatkan penerimaan daerah sekaligus kemudahan bagi wajib pajak serta mengurangi beban administrasi dari kedua belah pihak. Kemudahan melakukan kewajiban perpajakan bagi wajib pajak dinilai dapat meningkatkan kepatuhan wajib pajak. Tentunya hal tersebut berbanding lurus denganpenerimaan yang akan diterima oleh daerah melalui sektor perpajakan.

Dalam penelitian ini kami menganalisis tingkat kepatuhan Pengusaha Kena Pajak (PKP) sebagai subjek pajak/wajib pajak PPN karena berbagai perubahan dalam UU tentang PPN (terakhir UU No. 42 tahun 2009) mencakup juga berbagai aspek yang terkait erat dengan dimensi modernisasi pajak. Selain itu, kewajiban perpajakan PKP relatif mempunyai frekuensi tinggi karena SPT yang bersifat masa (bulanan).

Berdasarkan permasalahan yang telah dijelaskan maka penulis tertarik melakukan penelitian dengan judul “ Sosialisasi Sistem Administrasi Perpajakan 
Dalam Meningkatkan Kepatuhan Pengusaha Kena Pajak (PKP) Di Wilayah Tulungagung".

\section{LANDASAN TEORI}

\section{Pajak}

Menurut Rochmat Soemitro dalam buku “ Pengantar Singkat Hukum Pajak “( Eresco, Bandung, 1992), pajak adalah gejala masyarakat, artinya pajak hanya ada di dalam masyarakat. Masyarakat adalah kumpulan manusia yang pada suatu waktu berkumpul untuk tujuan tertentu. Masyarakat terdiri atas individu, individu yang mempunyai hidup sendiri dan kepentingan sendiri, yang dapat dibedakan dari hidup masyarakat dan kepentingan masyarakat. Namun individu tidak mungkin hidup tanpa adanya masyarakat. Negara adalah masyarakat yang mempunyai tujuan tertentu. Kelangsungan hidup negara juga berlangsung juga berarti berlangsungnya hidup masyarakat dan kepentingan masyarakat. Untuk kelangsungan hidup masing - masing diperlukan biaya. Biaya hidup individu, menjadi beban dari individu yang bersangkutan dan berasal dari penghasilan sendiri. Biaya hidup negara adalah utuk kelangsungan alat - alat negara, administratif negara, lembaga negara, dan seterusnya dan harus dibiayai dari penghasilan negara.

Menurut Undang - Undang Nomor 16 tahun 2009 tentang perubahan ke empat atas Undang - Undang Nomor 6 Tahun 1983 tentang Ketentuan Umum dan Tata Cara Perpajakan pada pasal 1 ayat 1 berbunyi pajak adalah kontribusi wajib kepada negara terutang oleh orang pribadi atau badan yang bersifat memaksa berdasarkan Undang - Undang, dengan tidak mendapatkan imbalan secara langsung dan digunakan untuk keperluan negara bagi sebesar - besarnya kemakmuran rakyat.

Dari beberapa definisi yang telah dijelasan bahwa pajak memiliki unsur - unsur :

1. Iuran dari rakyat kepada rakyat. Yang berhak memungut pajak hanyalah negara. Iuran tersebut berupa uang ( bukan barang ).

2. Berdasarkan undang - undang Pajak dipungut berdasarkan atau dengan kekuatan undang - undang serta atura pelaksanaannya. 
3. Tanpa jasa timbal atau kontraprestasi dari negara yang secara langsung dapat di tunjuk. Dalam pembayaran pajak tidak dapat ditunjukkan adanya kontraprestasi individual oleh pemerintahan.

4. Digunakan oleh rumah tangga negara, yakni pengeluaran - pengeluaran yang bermanfaat bagi masyarakat luas.

\section{Fungsi Pajak}

Berdasarkan penjabaran pengertian tentang pajak. Adapun fungsi pajak menurut Mardiasmo, menjelaskan : ${ }^{3}$

a. Fungsi Anggaran ( Budgetair ) Pajak berfungsi sebagai salah satu sumber dana bagi pemerintah untuk membiayai pengeluaran - pengelurnya.

b. Fungsi Mengatur ( Cregulered ) Pajak berfungsi sebagai alat untuk mengatur dan melaksanakan kebijaksanann pemerintah dalam bidang sosial maupun ekonomi.

\section{Syarat Pemungutan Pajak}

Dalam pemngutan pajak tentunta terdapat berbagai syarat yang harus dilakukan.

Menurut Mardiasmo sebagai berikut : ${ }^{4}$

a. Pemungutan pajak harus adil ( syarat keadilan ) Sesuai dengan tujuan hukum, yakni mencapai keadilan, undang - undang maupun pelaksanaan pemngutan pajak harus adil. Adil dalam perundang - undangan diantaranya mengenakan pajak secara umum dan merata, serta disesuaikan dengan kemampuan masing masing. Sedang adil dalam pelaksanaannya yakni dengan memberikan hak bagi Wajib Pajak untuk mengajukan keberatan, penundaan dalam pembayaran dan mengajukan banding kepada pengadilan pajak.

b. Pemungutan pajak harus berdasarkan undang - undang ( Syarat Yuridis ) Di Indonesia, pajak diatur dalam UUD 1945 Pasal 23 ayat 2. Hal ini memberikan jaminan hukum untuk menyatakan keadilan, bagi negara maupun warganya.

\footnotetext{
${ }^{3}$ Rahmatika.

${ }^{4}$ Rahmatika.
} 
c. Tidak menganggu perekonomian ( Syarat Ekonomis ) Pemungutan tidak boleh menganggu kelancaran kegiatan produksi maupun perdagangan, sehingga tidak meninggalkan kelesuhan perekonomian masyarakat.

d. Pemungutan pajak harus efisien ( Syarat Finansiil ) Sesuai fungsi budgetair, biaya pemungutan pajak harus lebh rendah daripada hasil pemungutannya.

e. Sistem pemungutan pajak harus sederhana Sistem pemungutan pajak yang sederhana akan memudahkan dan mendorong masyarakat dalam memenuhi kewajiban perpajakannya. Syarat ini telah dipenuhi oleh undang - undang perpajakan baru.

\section{Pengelompokkan Pajak}

Menurut Resmi (2011:7 ) terdapat tiga jenis pengelompokkan pajak yaitu, menurut golongan, menurut sifat dan menurut pemungutnya. Adapun menurut Mardiasmo ( 2016:7 ) juga terdapat tiga jenis pengelompokkan dalam pajak, yaitu: ${ }^{5}$

\section{a. Menurut Golongannya}

1.Pajak Langsung, yaitu pajak yang harus dipikul sendiri oleh Wajib Pajak dan tidak dapat dibebankan atau dilimpahkan kepada orang lain. Contoh : Pajak Penghasilan

2. Pajak Tidak Langsung, yaitu Pajak yang pada akhirnya dapat dibebankan atau dilimpahkan kepada orang lain. Contoh : Pajak Pertambahan Nilai

b. Menurut Sifatnya

1. Pajak Subjektif, yaitu pajak yang berpangkat atau berdasarkan pada subjeknya, dalam arti memerhatikan keadaan diri Wajib Pajak. Contoh : Pajak Penghasilan

\footnotetext{
${ }^{5}$ Rahmatika.
} 
2. Pajak Objektif, yaitu pajak yang berpangal pada objeknya, tanpa memerhatikan keadaan diri wajib pajak. Contoh : Pajak Pertambahan Niai dan Pajak Penjualan atas Barang Mewah.

c. Menurut Lembaga pemungutnya

1. Pajak Pusat, yaitu pajak yang dipungut oleh pemerintah pusat dan digunakan untuk membiayai rumah tangga negara. Contoh : Pajak Penghasilan, pajak Pertambahan Nilai dan Pajak Pertambahan Nilai atas Barang Mewah dan Bea Materai.

2. Pajak Daerah, yaitu pajak yang dipungut oleh pemerintah Daerah dan digunakan untuk membiayai rumah tangga daerah. Contoh : Pajak Propinsi dan pajak Kabupaten/Kota

\section{Cara Menghitung Pajak}

Menurut Resmi PPh terutang dihitung dari tarif dikalikan penghasilan kena pajak : Pajak Terutang $=$ Tarif Pajak $\mathrm{x}$ Penghasila Kena Pajak $=$ Tarif $\mathrm{x}($ Peredaran Bruto - pengeluaran/ biaya yang boleh dikurangkan Dalam menghitung pajak penghasilan yang terutang dibedakan antara Wajib pajak dalam negeri dan Wajib Pajak luar negeri. ${ }^{6}$

Bagi Wajib Pajak dalam negeri pada dasarnya terdapat dua cara untuk menentukan besarnya Penghasilan Kena Pajak, yaitu :

a. Penghitungan PPh dengan dasar pembukuan.

b. Penghitungan PPh dengan dasar pencatatan. Bagi Wajib Pajak luar negeri, Penghasilan Kena Pajak sebagai dasar penghitungan Pajak Penghasilan adalah sebesar penghasilan bruto, sehingga Pajak penghasilan yang terutang dengan cara mengalikan tarif pajak dengan penghasilan bruto.

\section{Pengertian Pajak Penghasilan Badan}

\footnotetext{
${ }^{6}$ Rahmatika.
} 
Menurut Erly Suandi Pajak Penghasilan termasuk dalam kategori sebagai pajak subjektif, artiya pajak dikenakan karena ada subjeknya yakni yang telah memenuhi kriteria yang telah diterapkan dalam peraturan perpajakan. ${ }^{7}$ Sehingga terdapat ketegasan bahwa apabila tidak ada subjek pajaknya, maka jelas tidak dapat dikenakan $\mathrm{PPh}^{8}$

Sedangkan menurut Ilyas dan Suhartono ( 2013:102), pengertian Pajak Penghasilan adalah pajak yang dikenakan terhadap subjek pajak penghasilan atas penghasilan yang akan diterima atau diperolehnya dalam Tahun Pajak. Subjek pajak yang menerima atau memperoleh penghasilan dalam Undang - undang No. 36 Tahun 2008 tentang Pajak Penghasilan ( PPh ) disebut Wajib Pajak. Undang undang No. 7 Tahun 1984 tentang Pajak Penghasilan ( PPh ) berlaku sejak 1 Januari 1984. Undang - undang ini telah beberapa kali mengalami perubahan dan terakhir kali diubah dengan Undang - Undang Nomor 36 Tahun 2008. Undang Undang Pajak penghasilan ( $\mathrm{PPh}$ ) mengatur pengenaan pajak Penghasilan terhadap subjek pajak berkenaan dengan penghasilan yang diterima atau diperolehnya dalam tahun pajak. Subjek pajak tersebut dikenai pajak apabila menerima atau memperoleh penghasilan. Subjek pajak yang menerima atau memperoleh penghasilan, dalam undang - undang PPh disebut Wajib Pajak. Wajib Pajak dikenai pajak atas penghasilan yang diterima atau diperolehnya selama satu tahun pajak atau dapat pula dikenai pajak untuk penghasilan dalam bagian tahun pajak apabila kewajiban pajak subjektifnya dimulai atau berakhir dalam tahun pajak. Pengertian badan adalah sekumpulan orang atau modal yang merupakan kesatuan baik yang melakukan usaha maupun yang tidak melakukan usaha yang meliputi perseroan terbatas, perseroan komanditer, perseroan lainnya, badan usaha milik negara ( BUMN ) atau badan usaha milik daerah ( BUMD ) dengan nama dan dalam bentuk apa pun, firma, kongsi, koperasi, dana pensiun, persekutuan, perkumpulam, yayasan, organisasi massa, organisasi sosial politik,

\footnotetext{
${ }^{7}$ Sabil, Dwiyatmoko Pujiwidodo, and Amin Setio Lestiningsih, 'Pengaruh E-Spt Pajak Penghasilan Dan Pemahaman Pajak Terhadap Kepatuhan Wajib Pajak', 2.2 (2018).

${ }^{8}$ Rahmatika.
} 
ataupun organisasi lainnya, lembaga , dan bentuk badan lainnya termasuk kontrak investasi kolektif dan bentuk usaha tetap.

\section{Bukan Subjek Pajak}

Sebagaimana lazimnya dalam perpajakan, maka dalam undang - undang Pajak penghasilan Indonesia ditetapkan pada yang tidak termasuk sebagai subjek pajak menurut Erly Suandi adalah sebagai berikut : ${ }^{9}$

a. Badan perwakilan negara asing

b. Pejabat - pejabat perwakilan diplomatik dan konsulat, atau pejabat - pejabat lain dari negara asing, demikian juga dengan orang - orang yang diperbantukan kepada mereka yang bekerja pada dan bertempat tinggal bersama - sama dengan mereka, dengan persyaratan bukan warga negara Indonesia, serta tidak menerima penghasilan lain dari luar jabatannya selama di Indonesia.

c. Organisasi - organisasi internasional yang ditetapkan oleh Menteri Keuangan.

\section{Tarif Pajak penghasilan Badan}

Menurut Firiandi, Aryanto, dan Priyono mengenai tarif PPh Badan yaitu : ${ }^{10}$

a. Tarif PPh pasal 17 ayat (1) huruf b, Wajib Pajak Badan dalam negeri dan bentuk usaha tetap adalah sebesar 28\%. Sebagaimana yang diatur dengan Peraturan Pemerintah, tarif tertinggi dapat diturunkan menjadi paling rendah $25 \%$ yang mulai berlaku sejak tahun pajak 2010 .

b. Tarif PPh pasal 17 ayat (2) huruf b, Wajib Pajak badan dalam negeri yang berbentuk perseroan terbuka yang paling sedikit $40 \%$ dari jumlah keseluruhan saham yang disetor diperdagangkan di bursa efek di Indonesia dan memenuhi persyaratan tertentu lainnya dapat memperoleh tarif sebesar 5\% lebih rendah.

c. Tarif PPh Pasal $31 \mathrm{E}$ ayat 1, wajib Pajak badan dalam negeri dengan peredaran bruto sampai dengan Rp. 50.000.000.000.- mendapat fasilitas berupa pengurangan tarif sebesar 50\% dari tarif sebagaimana dimaksud dalam pasal 17 ayat 1 huruf b dan ayat 2 huruf a yang dikenakan Penghasilan Kena Pajak dari bagian peredaran bruto sampai dengan Rp. 4.800.000.000,- .

\footnotetext{
${ }^{9}$ Rahmatika.

${ }^{10}$ Rahmatika.
} 


\section{Kepatuhan Wajib Pajak}

Menurut Kamus Umum Bahas Indonesia kepatuhan adalah tunduk atau patuh pada ajaran atau aturan. Jadi dapat diartikan bahwa kepatuhan perpajakan merupakan ketaatan, tunduk dan patuh serta melaksanakan ketentuan pajak sesuai dengan peraturan perundang - undangan perpajakan ${ }^{11}$. Sedangkan menurut ( Simanjutak dan Mukhlis, 2012:83-84) Kepatuhan pajak yaitu kesadaran Wajib Pajak untuk tunduk terhadap peraturan dan administrasi perpajakan yang berlaku tanpa perlu disertai dengan aktivitas tindakan dari otoritas pajak sebelumnya. Dan menurut Undang - undang No. 28 Tahun 2007 wajib Pajak adalah orang pribadi atau badan, meliputi pembayar pajak, pemotong pajak, dan pemungut pajak, yang mempunyai hak dan kewajiban perpajakan sesuai dengan peraturan perundang undangan perpajakan.

Kepatuhan pajak ( Tax Compliance ) berarti bahwa wajib pajak mempunyai kesediaan untuk memenuhi kewajiban pajaknya sesuai aturan yang berlaku tanpa perlu diadakan pemeriksaan, investigasi seksama, peringatan maupun anacaman dan penerapan sanksi baik hukum maupun administratis ( Gunadi, 2005:5). ${ }^{12}$ Menurut Siti Kurnia Rahayu ( 2010 : 138 ) 13 $^{13}$ mengatakan bahwa kepatuhan wajib pajak dapat didefinisikan sebagai suatu keadaan dimana wajib pajak memenuhi semua kewajiban perpajakan dan melaksanakan hak perpajakannya. Kepatuhan wajib pajak adalah wajib pajak mempunyai kesediaan untuk memenuhi kewajiban perpajakan sesuai dengan peraturan yang berlaku tanpa perlu diadakannya pemeriksaan, investigasi seksama, peringatan, maupun sanksi hukum maupun administrasi. Dari penjelasan kepatuhan tersebut dapat disimpulkan bahwa kepatuhan adalah tindakan Wajib Pajak yang melaksanakan semua kewajiban perpajakannya dan menikmati semua hak perpajakannya sesuai dengan ketentuan

\footnotetext{
${ }^{11}$ Rahmatika.

12 Putu Rara Susmita and Ni Luh Supadmi, 'PENGARUH KUALITAS PELAYANAN, SANKSI PERPAJAKAN, BIAYA KEPATUHAN PAJAK, DAN PENERAPAN E-FILING PADA KEPATUHAN WAJIB PAJAK', E-Jurnal Akuntansi Universitas Udayana.14.2 Februari (2016). 1239-1269 PENGARUH, 2016, 1239-69.

${ }^{13}$ Zuhdi, Topowijono, and Azizah.
} 
perundang - undangan yang berlaku. Predikat Wajib Pajak patuh dalam artian disiplin dan taat, tidak sama dengan Wajib Pajak yang berpredikat pembayar pajak dalam jumlah besar. Karena pembayar pajak terbesar sekalipun belum tentu memenuhi kriteria sebagai Wajib Pajak patuh, meskipun memberi kontribusi besar pada negara, jika masih memiliki tingkatan maupun dalam keterlambatan penyetoran pajak maka tidak dapat diberi predikat Wajib Pajak patuh.

\section{Kesadaran Wajib Pajak}

Menurut Kamus Umum Bahasa Indonesia, kesadaran adalah keadaan tahu, mengerti dan merasa. Kesadaran untuk memenuhi ketentuan ( hukum pajak ) yang berlaku tentu menyangkut faktor - faktor apakah ketentuan tersebut telah diketahui, diakui, dihargai, dan ditaati. Bila seseorang hanya mengetahui berarti kesadaran wajib pajak tersebut masih rendah. Kesadaran wajib pajak adalah suatu kondisi dimana wajib pajak mengetahui, memahami dan melaksanakan ketentuan perpajakan dengan benar dan sukarela. Pengetahuan dan pemahaman tentang perpajakan sangat penting karena dapat membantu wajib pajak dalam mematuhi aturan perpajakan.

Kesadaran perpajakan adalah keadaan mengetahui atau mengerti perihal pajak. Penilaian positif masyarakat wajib pajak terhadap pelaksanaan fungsi negara oleh pemerintah akan menggerakkan masyarakat untuk mematuhi kewajiban membayar pajak (Suyatmin, 2004 ). Sebagaimana diketahui bahwa dalam sistem perpajakan yang baru, wajib pajak diberikan keprcayaa untuk melaksanakan kegotong royongan nasional melalui sistem menghitung, memperhitungkan, membayar, melaporkan sendiri pajak yang terutang. Besarnya pajak dihitung sendiri oleh wajib pajak, kemudian membayar pajak terutang berdasarkan ketentuan - ketentuan perarutan perundang - undangan sesuai dengan ketentuan pajak yang berlaku. Menurut Ritongga ( 2011 ) kesadaran adalah ${ }^{14}$ perilaku atau sikap terhadap suatu objek yang melibatkan anggapan dan perasaan serta kecenderungan untuk bertindak sesuai objek tersebut. dengan demikian dapat

${ }^{14}$ Risky Riyanda and others, 'Pengaruh Sanksi Administrasi Sosialisasi Perpajakan Dan Kesadaran Wajib Pajak Terhadap Kepatuhan Penyampaian Spt Tahunan Wajib Pajak Orang Pribadi', 1.1 (2014). 
dikatakan bahwa kesadaran pajak dalam membayar pajak merupakan perilaku wajib pajak berupa pandangan atau perasaan yang melibatkan pengetahuan, keyakinan, dan penalaran disertai kecenderungan yang diberikan oleh system dan ketentuan pajak tersebut. Wajib pajak harus melaksanakan aturan itu dengan benar dan sukarela. Jadi dapat didefinisikan, kesadaran wajib pajak adalah suatu kondisi dimana wajib pajak mengetahui, mengakui, menghargai dan menaati ketentuan perpajakan yang berlaku serta memiliki kesungguhan dan keinginan untuk memenuhi kewajiban pajaknya.

\section{Pengertian Sosialisasi Perpajakan}

Sosialisasi merupakan suatu upaya yang dilakukan Dirjen Pajak melalui berbagai metode untuk memberikan informasi terkait segala peraturan dan kegiatan yang berhubungan dengan perpajakan agar dapat dilaksanakan oleh masyarakat pada umumnya khususnya wajib pajak, baik orang pribadi maupun badan usaha (Direktorat Jenderal Pajak, 2011). ${ }^{15}$

Metode Sosialisasi Perpajakan Program-program yang telah dilakukan berkaitan dengan kegiatan sosialisasi pajak yang dimaksudkan untuk meningkatkan kepatuhan wajib pajak antara lain (Putra et al, 2014).

a. Mengadakan penyuluhan-penyuluhan tentang Memasang spanduk yang bertemakan pajak.

b. Memasang iklan layanan masyarakat di berbagai stasiun televisi.

c. Mengadakan acara tax goes to campus yang diisikan dengan berbagai acara yang menarik mulai dari debat pajak sampai dengan seminar pajak dimana hal tersebut bertujuan untuk menimbulkan pemahaman tentang pajak kepada masyarakat.

d. Memberikan penghargaan terhadap wajib pajak patuh pada setiap Kantor Pelayanan Pajak (KPP).

\section{Pemahaman Wajib Pajak}

\footnotetext{
${ }^{15}$ Riyanda and others.
} 
Pemahaman wajib pajak sangat mempengaruhi wajib pajak dalam memenuhi kewajiban perpajakannya. ${ }^{16}$ Kurangnya pemahaman dan pengetahuan wajib pajak terhadap ketentuan Peraturan-Peraturan Perundang-Undangan Perpajakan menyebabkan wajib pajak merasa tidak memiliki kewajiban untuk membayar pajak. Melantri menjelaskan "proses pemahaman merupakan suatu proses belajar melalui pengamatan berusaha memahami segala jenis informasi yang berkaitan dengan pajak". Pemahaman pajak juga dapat diartikan sebagai suatu proses perbuatan, atau cara yang dilakukan oleh wajib pajak untuk mengetahui, mengerti, dan memahami akan informasi pajak. Hal ini dapat berarti bahwa unsur pertanyaan /sampel tersebut diatas memiliki respon yang buruk dalam rangka pemenuhan kewajiban Pajak Bumi dan Bangunan di Kabupaten Tulungagung yang harus segera dicari penyebabnya dan dilakukan upaya perbaikan terhadap hal tersebut.(Prabowo 2014). ${ }^{17}$

\section{Manfaat perpajakan}

\section{Manfaat Bagi Pemerintah}

Menurut mardiasmo (2016) melihat dasar pedoman kegiatan kerja profesi Konsultan Pajak dan dasar pedoman kerja Direktorat Jenderal Pajak adalah samasama peraturan perundang-undangan perpajakan yang berlaku ${ }^{18}$, maka pernah dikatakan bahwa Konsultan Pajak adalah merupakan mitra Direktorat Jenderal Pajak. Istilah mitra ini juga tercantum dalamMukadimah Anggaran Dasar Ikatan Konsultan Pajak Indonesia. Istilah mitra di sini bukanlah berarti bahwa Konsultan Pajak adalah pegawai pajak yang tidak dibayar pemerintah dan merupakan perpanjangan tangan dari Direktorat Jenderal Pajak yang harus mengekor saja, tetapi mitra dalam arti memiliki kemandirian atau independensi. Mitra di sini hendaknya diartikan bahwa antara Konsultan Pajak dan Direktorat Jenderal Pajak mempunyai pedoman kerja yang sama. Selain itu, dalam pelaksanaan sistem self

\footnotetext{
${ }^{16}$ Susmita and Supadmi.

${ }^{17}$ Rachmad Gesah Mukti Prabowo, 'ANALISIS PEMENUHAN PEMBAYARAN PAJAK BUMI DAN BANGUNAN UNTUK MENINGKATKAN PENERIMAAN SEKTOR PAJAK', 1.1 (2014), 81-95.

${ }^{18}$ Zuhdi, Topowijono, and Azizah.
} 
assessment dewasa ini kedua pihak di atas juga harus menyebarluaskan dan memasyarakatkan peraturan perundangundangan perpajakan yang berlaku sehingga masyarakat Wajib Pajak dalam melaksanakan kewajiban perpajakannya serta menuntut hak perpajakannya dapat sesuai dengan ketentuan perundangundangan perpajakan yang berlaku. Selain itu, manfaat lain adanya profesi Konsultan Pajak bagi pemerintah antara lain:

a. Konsultan harus ikut menyadarkan Wajib Pajak agar patuh melaksanakan kewajiban perpajakannya yang merupakan kewajiban pengabdian kepada negara dalam ikut menjamin kelangsungan pembangunan nasional. Hal ini sangat berkaitan erat dengan anggapan masyarakat Wajib Pajak bahwa kewajiban pembayaran pajak adalah merupakan suatu beban pengeluaran yang bagaimanapun juga harus selalu diupayakan penghematan.

b. Konsultan Pajak juga ikut mengusahakan terciptanya iklim perpajakan nasional yang lebih sehat dengan melakukan kontrol sosial yaitu meneliti apakah aparat pajak dalam menuntut hak penerimaan negara dari sektor pajak sesuai dengan ketentuan perundang-undangan perpajakan yang berlaku.

c. Konsultan Pajak diharapkan dapat ikut meningkatkan kualitas mutu pelayanan perpajakan kepada masyarakat Wajib Pajak.

\section{Manfaat Bagi Wajib Pajak}

Sekarang ini pelaksanaan sistem perpajakan di Indonesia adalah dengan menerapkan sistem self assessment, di mana kepada Wajib Pajak diberikan kepercayaan yang lebih besar untuk menghitung dan melaporkan sendiri pajaknya. Dalam melaksanakan sistem self assessment tersebut dituntut adanya pemahaman dan penguasaan dari segenap lapisan masyarakat Wajib Pajak mengenai materi ketentuan perundang-undangan perpajakan, baik mengenai hakhak Wajib Pajak maupun kewajibannya sebagai Wajib Pajak. Selain itu kepastian hukum bagi Wajib Pajak harus dijamin yang artinya law enforcement.

Undang-Undang Perpajakan harus benar-benar dilaksanakan dengan konsekuen, yaitu baik aparatur pajak maupun Wajib Pajak harus samasama mematuhi ketentuan perundang-undangan perpajakan yang berlaku. Apabila dilihat dari jasa yang diberikan oleh Konsultan Pajak seperti yang disebutkan di 
atas, maka manfaat atau peranan Konsultan Pajak bagi Wajib Pajak adalah berkaitan dengan pemenuhan kewajiban perpajakan dari Wajib Pajak, yang antara lain:

a. Memberikan jasa tax compliance audit.

b. Membantu Wajib Pajak dalam membuat perhitungan pajaknya yang harus dibayar dan sekaligus memberikan pengarahan dalam pengisian Surat Pemberitahuan (SPT) sebagai laporan tahunannya yang harus sesuai dengan ketentuan perundangundangan perpajakan.

c. Memberikan konsultasi dalam masalah perpajakan yang dihadapi

\section{Usaha Mikro Kecil dan Menengah}

Berdasarkan Undang-Undang Nomor 20 Tahun 2008 tentang Usaha Mikro, Kecil dan Menengah (UMKM) ada beberapa kriteria yang dipergunakan untuk mendefinisikan pengertian dan kriteria Usaha Mikro, Kecil dan Menengah. ${ }^{19}$ Kriteria kelompok usaha mikro adalah usaha produktif milik orang perorangan dan/atau badan usaha perorangan yang memiliki hasil penjualan tahunan Rp 300.000.000,00 dan memilki kekayaan bersih (tidak termasuk tanah/bangunan) paling banyak Rp 50.000.000,00.

Kriteria usaha kecil adalah usaha ekonomi produktif yang berdiri sendiri, yang dilakukan oleh orang perorangan atau badan usaha yang bukan merupakan anak perusahaan atau bukan cabang perusahaan yang dimiliki, dikuasai, atau menjadi bagian baik langsung maupun tidak langsung dari usaha menengah atau usaha besar yang yang memiliki hasil penjualan antara Rp 300.000.000,00 sampai dengan Rp 2.500.000.000,00 dan memiliki kekayaan bersih antara Rp 50.000.000,00 sampai dengan Rp 500.000.000,00. Kriteria usaha menengah adalah usaha ekonomi produktif yang berdiri sendiri, yang dilakukan oleh orang perseorangan atau badan usaha yang bukan merupakan anak perusahaan atau cabang perusahaan yang dimiliki, dikuasai, atau menjadi bagian baik langsung maupun tidak langsung dengan Usaha Kecil atau usaha besar dengan dengan penjualan tahunan mencapai $\mathrm{Rp} 2.500 .000 .000,00$ sampai dengan $\mathrm{Rp}$

\footnotetext{
${ }^{19}$ Riyanda and others.
} 
50.000.000.000 dan memiliki kekayaan bersih lebih besar dari Rp $500.000 .000,00$.

\section{Usaha mikro}

Menurut Mufti Rahmatika (2010) Pengertian usaha mikro dalam UndangUndang Nomor 20 Tahun 2008 tentang UMKM Pasal 1 angka1 yang dimaksud dengan usaha mikro adalah ${ }^{20}$ usaha produktif milik orang atau perseorangan dan/atau badan usaha perseorangan yang mempunyai kriteria sebagai berikut: memiliki kekayaan paling banyak Rp.50.000.000,00 (lima puluh juta rupiah) tidak termasuk tanah dan bangunan tempat usaha, atau memiliki hasil penjualan tahunan paling banyak Rp.300.000.000,00 (tiga ratus juta rupiah). Ciri-ciri usaha mikro:

a. Jenis barang/komoditi usahanya tidak selalu tetap, sewaktu-waktu dapat berganti;

b. Tempat usahanya tidak selalu menetap, sewaktu-waktu dapat pindah tempat

c. Belum melakukan administrasi keuangan yang sederhana sekalipun, dan tidak memisahkan keuangan keluarga dengan keuangan usaha;

d. Sumber daya manusianya (pengusahanya) belum memiliki jiwa wirausaha yang memadai;

e. Tingkat pendidikan rata-rata relatif sangat rendah;

f. Umumnya belum akses kepada perbankan, namun sebagian dari mereka sudahvakses ke lembaga keuangan non bank;

g. Umumnya tidak memiliki izin usaha atau persyaratan legalitas lainnya termasuk NPWP.

\section{Usaha kecil}

Menurut Mufti Rahmatika (2010). Sedangkan kriteria usaha kecil adalah ${ }^{21}$ sebagai berikut: usaha ekonomi produktif yang berdiri sendiri yang dilakukan oleh orang perseorangan atau bandan usaha yang bukan merupakan anak perusahaan

20 Prabowo.

${ }^{21}$ Prabowo. 
atau cabang perusahaan yang dimiliki, dikuasai, atau menjadi bagian baik langsung maupun tidak langsung dari usaha menengahatau usaha kecil yang memenuhi kriteria sebagai berikut: memlikiki kekayaan bersih lebih dari Rp.50.000.000,00 (lima puluh juta rupiah) sampai dengan paling banyak Rp.500.000.000,00 (lima ratus juta rupiah) tidak termasuk tanah dan bangunan tempat usaha. Atau memiliki penjualan tahunan lebih dari Rp.300.000.000,00 (tigaratus juta rupiah) sampai dengan paling banyak Rp.2.500.000.000,00 (dua milyar lima ratus juta rupiah). Ciri-ciri usaha kecil:

a. Jenis barang/komoditi yang diusahakan umumnya sudah tetap tidak gampang berubah;

b. Lokasi/tempat usaha umumnya sudah menetap tidak berpindah-pindah;

c. Pada umumnya sudah melakukan administrasi keuangan walau masih sederhana,keuangan perusahaan sudah mulai dipisahkan dengan keuangan keluarga, sudah membuat neraca usaha;

d. Sudah memiliki izin usaha dan persyaratan legalitas lainnya termasuk NPWP;

e. Sumber daya manusia (pengusaha) memiliki pengalaman dalam berwira usaha;

f. Sebagian sudah akses ke perbankan dalam hal keperluan modal;

g. Sebagian besar belum dapat membuat manajemen usaha dengan baik seperti business planning

\section{Usaha menengah}

Menurut Mufti Rahmatika (2010). Usaha Menegah adalah ${ }^{22}$ usaha ekonomi produktif yang berdiri sendiri, yang dilakukan oleh orang perseorangan atau badan usaha yang bukan merupakan anak perusahaan atau cabang perusahaan yang dimiliki, dikuasai, atau menjadi bagian baik langsung maupun tidak langsung dengan usaha kecil atau usaha besar dan kriteria usaha menengah adalah sebagai berikut: memiliki kekayaan bersih lebih dari Rp.500.000.000,00 (lima ratus juta rupiah) sampai dengan paling banyakRp.10.000.000.000,00 (sepuluh milyar rupiah) tidak termasuk tanah dan bangunan tempat usaha, atau memiliki hasil

\footnotetext{
22 Prabowo.
} 
penjualan tahunan lebih dari Rp.2.500.000.000,00 (dua milyar lima ratus juta rupiah) sampai dengan paling banyak Rp.50.000.000.000.,00 (lima puluh milyar rupiah). Ciri-ciri usaha menengah:

a. Pada umumnya telah memiliki manajemen dan organisasi yang lebih baik, lebih teratur bahkan lebih modern, dengan pembagian tugas yang jelas antara lain, bagian keuangan, bagian pemasaran dan bagian produksi;

b. Telah melakukan manajemen keuangan dengan menerapkan sistem akuntansi dengan teratur, sehingga memudahkan untuk auditing dan penilaian atau pemeriksaan termasuk olehperbankan;

c. Telah melakukan aturan atau pengelolaan dan organisasi perburuhan, telah ada Jamsostek, pemeliharaan kesehatan dll;

e. Sudah memiliki segala persyaratan legalitas antara lain izin tetangga, izin usaha, izin tempat, NPWP, upaya pengelolaan lingkungan dll;

f. Sudah akses kepada sumber-sumber pendanaan perbankan;

g. Pada umumnya telah memiliki sumber daya manusia yang terlatih dan terdidik

\section{METODE PENELITIAN}

\section{Jenis Penelitian}

Penelitian ini mengkaji pelaksanaan sosialisasi perpajakan di Wilayah Tulungagung untuk meningkatkan kesadaran pengusaha dalam membayar Pajak. Dengan demikian, penelitian ini hanya mengkaji satu variabel atau variabel tunggal yaitu pelaksanaan sosialisasi perpajakan untuk meningkatkan kesadaran pengusaha dalam membayar Pajak.

Penelitian ini merupakan penelitian deskriptif dimana penulis memberikan gambaran tentang upaya sosialisasi perpajakan untuk meningkatkan kesadaran pengusaha dalam membayar PKP serta kendala-kendala yang dialami dalam penyampaian sistem administrasri Pengusaha kena pajak (PKP). Informan dalam penelitian ini adalah beberapa pengusaha dan BAPENDA yang dipandang dapat memberikan informasi berkenaan dengan masalah yang diteliti. 


\section{Variabel Penelitian}

Penelitian ini terdiri dari aspek pajak pengusaha (PKP) sebagai dasar penelitian yang memerlukan sosialisasi sistem administrasi pajak agar membantu meningkatkan kesadaran akan pajak kususnya pengusaha di Kabupaten Tulungagung.

\section{Lokasi Penelitian}

Dalam penelitian ini, peneliti melakukan observasi pada beberapa pengusaha di Kabupaten Tulungagung

\section{Populasi dan Sampel}

Populasi dalam penelitian ini adalah pengusaha di Kabupaten Tulungagung, namun yang menjadi sampel dalam penelitian ini sebagian dari populasi, hal ini dikarenakan bentuk penelitian deskripsi kualitatif dengan mewakilkan beberapa pengusaha dengan dipilih berdasarkan kriteria atau biasa disebut purposive sampling.

\section{Metode Pengumpulan Data}

Teknik Pengumpulan Data dilakukan dengan cara:

a) Observasi yang digunakan sebagai teknik pertama dilakukan untuk mengamati secara langsung di lapangan yaitu usaha yang dilakukan oleh Badan Pendapatan Daerah Kota Tulungagung untuk meningkatkan kesadaran pengusaha dalam membayar Pajak PKP.

b) Dokumentasi, cara pengumpulan data dengan cara membaca, mempelajari, mengutip, dan merangkum data yang berkaitan dengan masalah yang diteliti.

c) Wawancara yaitu Pengumpulan data yang dilakukan dengan cara tanya jawab dengan pihak yang dianggap kompeten dengan masalah yang diteliti mengenai pelaksanaan sosialisasi dan kendala yang dihadapi dalam mensosialisasikan kewajiban membayar Pengusaha Kena Pajak (PKP). 


\section{Analisa Data}

Analisis Data yang digunakan dalam penelitian ini yaitu mengunakan analisis deskriptif dengan menggambarkan kenyataan atau keadaan-keadaan atas suatu objek dalam bentuk uraian kalimat berdasarkan keterangan-keterangan dari pihakpihak yang berhubungan langsung dengan penelitian ini

\section{PEMBAHASAN}

\section{Upaya Badan Pendapatan Daerah dalam Sosialisasi Sistem Administrasi Pajak Untuk Pengusaha Kena Pajak (PKP)}

Bapenda selaku badan yang bertugas mengurusi pajak melakukan berbagai cara untuk menumbuhkan kesadaran pajak dikalangan pengusaha. Salah satu cara BAPENDA adalah sosialisasi kepada masyarakat maupun kepada pengusaha yang ada di Tulungagung. Pembinaan masyarakat dapat dilakukan melalui berbagai upaya, antara lain pemberian penyuluhan pengetahuan perpajakan baik melalui media massa maupun penerapan langsung kepada masyarakat. Fakta yang dapat dilihat BAPENDA bekerja sama dengan Pemerintah desa telah melakukan upaya sosialisasi perpajakan di balai desa. Selain itu mereka juga bekerja sama dengan beberapa pihak untuk dapat melakukan sosialisasi baik melalui media elektronik maupun media cetak. ${ }^{23}$

Demi meningkatkan efisiensi dan efektivitas penyelenggaraan pemerintahan dan layanan masyarakat, diperlukan sumber-sumber pendapatan daerah. Salah satunya melalui pungutan pajak bumi dan bangunan perkotaan dan perdesaan (PBB-P2).Untuk itu, Badan Pendapatan Daerah (Bapenda) Tulungagung menggelar sosialisasi penyampaian SPPT dan pemungutan PBB-P2 tahun 2020. Bertempat di Crown Victoria Hotel, acara dihadiri seluruh kasi pemerintahan (kasipem) kecamatan, kepala desa (kades ), lurah, serta koordinator penyampaian PBB-P2 dan BPHTB se-Kabupaten Tulungagung.

${ }^{23}$ Prabowo. 
Plt Kepala Bapenda Tulungagung Sugiono, melalui Kabid Pendataan dan Penetapan Tumijan mengatakan, sosialisasi ini sangat penting. Mengingat untuk memenuhi target PBB-P2, diperlukan dukungan dari para pemangku kebijakan. Baik di tingkat kecarnatan maupun desa. "Tahun 2020 ini ketetapan PBB-P2 sebesar Rp 29,3 miliar dan jumlah wajib pajak sebanyak 652.625 lembar SPPT. Nah, target kami harus tercapai di atas 90 persen. Untuk itu, perlu dukungan berbagai pihak," jelasnya.(radar tulungagung)

Kedua, Web Site. Bapenda Tulungagung menggunakan berita online dalam memberikan informasi kepada masyarakat, web yang sering meliput kegiatan perpajakan yang dilakukan oleh Bapenda Tulungagung di bapenda.tulungagung.go.id.. di web site tersebut dimuat tata cara membayar pajak dan informasi terbaru terkait pajak.

Dengan adanya informasi tentang administrasi pembayaran pajak pada saat sosialisasi sangat membantu kepada pada masyarakat untuk membayar pajak. Selain itu BAPENDA memberikan ilmu kepada tenaga teknis sebagai garda terdepan pelayanan kepada masyarakat, sehingga masyarakat dapat dengan mudah menerima informasi yang diberikan oleh petugas teknis. Diharapkan pengusaha yang belum mengetahui wajib pajak segera mendaftarkan diri untuk membayar pajak.

\section{Kendala yang Dihadapi BAPENDA dalam Sosialisasi}

Kegiatan sosialisasi yang dilakukan terus bertambah tetapi jumlah pembayar pajak masih sangatlah sedikit masih banyak sekali pengusaha yang belum membayar pajak, kendala yang dialami sebelum dan sesudah dilaksanakan sosialisasi kendala dari masyarakat dan pihak BAPENDA. Dalam pelaksanakan penyuluhan, terutama penyuluhan di desa karena kurangnya minat masyarakat untuk untuk menghadiri penyuluhan tersebut. Selain kurangnya minat masyarakat kegiatan yang diadakan hanya sekali dan tidak ada tindak lanjutnya.

Terdapat beberapa faktor penyebab turunnya kesadaran masyarakat. Data ini didapatkan setelah mewawancarai pengusaha di bidang pakaian, kuliner,dan 
teknologi. Faktor ini dapat menurunkan tingkat kesadaran dan kepedulian sukarela Wajib Pajak. Antara lain:

1) Adanya anggapan masyarakat bahwa timbal balik (kontra prestasi) pajak tidak bisa dinikmati secara langsung, bahkan wujud pembangunan sarana prasana belum merata, meluas, apalagi menyentuh pelosok tanah air.

2) Adanya anggapan masyarakat bahwa tidak ada keterbukaan pemerintah terhadap penggunaan uang pajak

3) Prasangka negatif kepada aparat perpajakan harus digantikan dengan prasangka positif. Sebab, prasangka negatif ini akan menyebabkan para wajib pajak bersikap defensif dan tertutup. Mereka akan cenderung menahan informasi dan tidak co operatif. Mereka akan berusaha memperkecil nilai pajak yang dikenakan pada mereka dengan memberikan informasi sesedikit mungkin.

\section{KESIMPULAN DAN SARAN}

\section{Kesimpulan}

Berdasarkan hasil penelitian dan pembahasan pada bab sebelumnya maka dapat ditarik kesimpulan sebagai berikut: Kegiatan sosialisasi yang dilakukan oleh BAPENDA Tulungagung dalam upaya meningkatkan kesadaran masyarakat dalam membayar Pajak merupakan langkah yang baik. BAPENDA memberikan program untuk memudahkan masyarakat dalam mengetahui informasi tentang pajak secara langsung maupun melalui media informasi seperti website BAPENDA Tulungagung.

\section{Saran}

1. Masyarakat yang terdiri dari berbagai golongan membutuhkan berbagai pendekatan dalam halnya sosialisasi yang dilakukan BAPENDA Tulungagung secara langsung maupun media. Sehingga membutuhkan kegiatan secara berkala untuk dapat melihat perkembangan masyarakat dalam membayar pajak.

2. Perlu melakukan koordinasi dengan instansi daerah untuk memudahkan sosialisasi yang akan dilaksanakan oleh BAPENDA Tulungagung. 


\section{DAFTAR PUSTKA}

Prabowo, Rachmad Gesah Mukti, 'ANALISIS PEMENUHAN PEMBAYARAN PAJAK BUMI DAN BANGUNAN UNTUK MENINGKATKAN PENERIMAAN SEKTOR PAJAK', 1.1 (2014), 81-95

Rahmatika, Mufti, 'ANALISIS FAKTOR-FAKTOR YANG BERPENGARUH TERHADAP KESADARAN KEWAJIBAN PERPAJAKAN PADA SEKTOR USAHA KECIL DAN MENENGAH (UKM) Diajukan', 2010

Riyanda, Risky, Rama Putra, Siti Ragil Handayani, Fakultas Ilmu Administrasi, and Universitas Brawijaya, 'Pengaruh Sanksi Administrasi Sosialisasi Perpajakan Dan Kesadaran Wajib Pajak Terhadap Kepatuhan Penyampaian Spt Tahunan Wajib Pajak Orang Pribadi', 1.1 (2014)

Sabil, Dwiyatmoko Pujiwidodo, and Amin Setio Lestiningsih, 'Pengaruh E-Spt Pajak Penghasilan Dan Pemahaman Pajak Terhadap Kepatuhan Wajib Pajak', 2.2 (2018)

Susmita, Putu Rara, and Ni Luh Supadmi, 'PENGARUH KUALITAS PELAYANAN, SANKSI PERPAJAKAN, BIAYA KEPATUHAN PAJAK, DAN PENERAPAN E-FILING PADA KEPATUHAN WAJIB PAJAK', $E$ Jurnal Akuntansi Universitas Udayana.14.2 Februari (2016). 1239-1269 PENGARUH, 2016, 1239-69

Zuhdi, Firdaus Aprian, Topowijono, and Devi Farah Azizah, 'PENGARUH PENERAPAN E-SPT DAN PENGETAHUAN PERPAJAKAN TERHADAP KEPATUHAN WAJIB PAJAK (Studi Pada Pengusaha Kena Pajak Yang Terdaftar Di KPP Pratama Singosari)', 7.1 (2015), 1-7 